to understand exactly what proof must be submitted. A large number of cases have occurred where subsequent changes in the status of the soldier's eligible relatives or dependents, including persons to be added to or removed from the list of beneficiaries, have not been properly reported. For example, an application for a family allowance has been made for a wife, some time later a child is born for whom a family allowance is also desired. The change should be reported on the official change of status form and documentary evidence should be submitted in support of the change. The evidence required is the same as that required in making similar claims on original applications.

The original legislation for family allowances for the dependents of men in the armed forces was enacted soon after the need for the same became apparent. It is to be recognized that for some the allowances provided for even under the liberal amendments will be insufficient to meet needs because the allowances are uniform for dependents of specified types and do not take into account wide differences in living costs and family circumstances. On the other hand, there are many who do not need any family allowance at all because of adequate income from other sources. It is difficult if not impossible to do exact justice to all in such a tremendous emergency undertaking. The amendments certainly do serve to achieve to some further degree the utilitarian principle of the greatest good for the greatest number. The system now in operation under the Servicemen's Dependents Allowance Act of 1942 , as amended, is certainly the most liberal wartime provision ever made by any government in the history of the world for its fighting forces, ${ }^{5}$ with a resultant vast benefit to their welfare and morale.

\title{
RECENT DEVELOPMENTS IN THE "VESTED RIGHTS" THEORY OF CONTRACTS
}

Advocated by Beale, the Restatement, and the Hornbook as just and logical, ${ }^{,}$the principle that a contract should be, and must be, governed by the "law" of the state where it was "made" (i.e., "where the last act necessary to make it a binding agreement takes place"2) has long been

5 For a survey of the allowance systems in other countries in I940, see Marianne Sakmann, Foreign Provisions for the Dependents of Mobilized Men, Social Security Bulletin, Vol. 4, No. 4, April, I94I.

I 2 Beale, A Treatise on the Conflict of Laws rogr (1935), hereafter cited as Beale; Rest., Conflict of Laws $\& 3$ II (I934), hereafter cited as Rest.; Goodrich, Handbook of the Conflict of Laws 274 (1938), hereafter cited as Goodrich.

2 Goodrich, p. 262. 
accepted and supposedly followed by American courts in conflicts of laws cases. ${ }^{3}$ Under this rule, the court of the forum has simply to look to "the general law of contracts," 4 apply it to the facts in controversy, and ascertain the place "in which .... the principal event necessary to make a contract occurs." When ascertained, that place is "the place of contracting." If an enforceable contractual duty there arises under its laws, "the duty thus imposed will be recognized and enforced in common law states. ..." While, on this reasoning, only the law of "the place of contracting" regulates the validity of the contract, apart from special exceptions, ${ }^{7}$ the Court enunciated a parallel doctrine whereby a state could regulate parties to a contract executed elsewhere if the parties were "doing business" within the state. As was stated in the Allgeyer case, "the right to contract [within the State] in relation to persons or property or to do business within the jurisdiction of the State may be regulated and sometimes prohibited when the contracts or business conflict with the policy of the State as contained in its statutes." Note that doing business is distinguished from making contracts. Both are valid subjects of regulation. Thus, a business locally carried on but involving contracts executed elsewhere must conform to the local law, even if the extent of the regulation must, under the Constitution, be limited to the business done within the state. Where local statutes prescribe regulations contrary to those of "the place of contracting," an obvious inconsistency results. This note will briefly describe some of the varied attempts to resolve this inconsistency.

In Nere York Life Ins. Co. v. Cravens ${ }^{9}$ the Supreme Court held that a

3 a Beale, p. Ir73.

4 Rest., $\$ 3 x x$, comment (d).

5 Ibid. "Principal event" is synonymous with "last act." Rest., $\$ \S 3$ I 2-2r. Cook indicates Beale has extended this.rule too far. Cook, 'Contracts' and the Conflict of Laws 3 IIll. I. Rev. . I43, I73-77 ( 1936 ), reprinted in Cook, The Logical and Legal Bases of the Conflict of Laws $347,382-87$ (I942). For Beale's attitude see 2 Beale, p. Io72.

${ }^{6}$ Rest., $\S 395$. This is the "vested rights" theory. See Cook, op. cit. supra, note 5.

7 The "law of the place of performance" is said to govern as to such matters as the manner, the time, the locality, and the sufficiency of performance, "the person or persons by whom or to whom performance shall be made or rendered," and the "excuse for non-performance." Rest., § 358; Goodrich, pp. 293-97. For the attempted distinction between a "question of obligation" governed by "the place of contracting" and a "question of performance" governed by "the place of performance" see Rest., $\$ 358$, comment (b); Goodrich, p. 294. The distinction

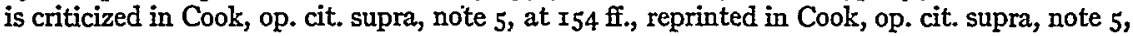
at $359 \mathrm{ff}$.

As to causes of action contrary to "the strong public policy of the forum," see Rest., §6r2; Goodrich, pp. 23I-34; Loucks v. Standard Oil Co., 224 N.Y. 99, r20 N.E. I98 (rgr8). Cf. Mertz v. Mertz, 27I N.Y. 466, 3 N.E. (2d) 597 (r936).

${ }^{8}$ Allgeyer v. Louisiana, 165 U.S. 578, 59 (I897). Italics added.

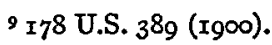


contract entered into between a Missouri citizen and a foreign insurance company "doing business" within Missouri could be constitutionally regulated by Missouri statutes even though the contract was not "made" in Missouri.. The power to regulate was held to stem from the doing of business within the state. In New York Life Ins. Co.v. Dodge, , $^{\mathrm{II}}$ a case arising seventeen years later, the Court was asked to determine the power of Missouri to apply its non-forfeiture statute to a loan agreement "made" in New York between residents of Missouri and an insurance company admittedly "doing business" in Missouri. The loan agreement was made subsequently to the issuance in Missouri of an insurance policy which the Court conceded was a Missouri contract and which would be substantially affected by the treatment of the later contract. The Court mechanically applied the rule stated above: the "last act" making the loan binding was performed in New York; therefore the "place of contracting" was New York; therefore New York law governed; therefore Missouri law did not. The Court attempted to distinguish the Cravens case by saying: "the controversy [in the Cravens decision] related to the interpretation and effect of an original policy-not a later good faith agreement between the parties."'12 The Court ignored the fact that the contract involved in the Cravens case was apparently executed wothout the state of Missouri and that Missouri's power to regulate depended on the foreign company's doing business within Missouri, not on the contract's being a Missouri contract. ${ }^{{ }^{3}}$ Four years later, in Mutual Life Ins. Co. v. Liebing, ${ }^{x_{4}}$ the Court was faced with precisely the same problem. This time, however, the Court construed the original policy of insurance as making loans on the policy mandatory, whereas it thought that in the Dodge case the home office of the company in New York had discretion. This distinction enabled the Court to call the loan agreement a Missouri contract, and hence, subject to Missouri statutes. The Court reasoned as follows: "as soon as the application [for the loan] was delivered to a representative of the company in Missouri, the offer in the policy [to make the loan] was accepted and the new contract complete, and therefore subject to Missouri law. If, how-

${ }^{10}$ The Cravens case has usually been cited as a case where Missouri could regulate because the contract was "made" in Missouri. See Carnahan, Conflict of Laws and Life Insurance Contracts 553 (1942). But stress is equally laid on the doing of business in Missouri, and the "place of contracting" is not made clear.

${ }^{x} 246$ U.S. 357 (xgr8).

22246 U.S. 357,373 (rgI8).

${ }_{33}$ The Court also thought that the loan contract was "fair." But see note ro, supra.

${ }^{4} 259$ U.S. 209 (I922). 
ever, the application should be regarded as only an offer, the effective ${ }^{\text {ts }}$. acceptance of it did not take place until the check was delivered to Blees [the insured], which again was in Missouri where he lived." ${ }^{36}$ Yet in the Dodge case the home office mailed the check to the insured, so it could have been there said also that "the effective acceptance did not take place until the check was delivered." The language in the original policies of both cases also deserves comparison. In the Dodge case the policy had stated: "Cash loans can be obtained by the insured on the sole security of this policy on demand at any time after this policy has been in force two full years .... [providing certain conditions were met]." "r7 The original policy in the Liebing case provided: "the company will .... loan amounts within the limits of the cash surrender value .... [providing certain conditions were observed, including the assigning of the policy as security]." ${ }^{8} 8$ To the writer there seems no substantial difference in meaning between the two provisions. The only logically fair inference is that the Liebing case in effect overruled the Dodge decision. ${ }^{19}$ The disturbing aspect of the Dodge and Liebing cases, however, is in their reasoning. In spite of their opposite conclusions both decisions rest on the same theory: the law to be applied should be the law of "the place of contracting." In the Dodge case the Court thought it saw "the last act" in a different place than it thought it saw it in the Liebing case. Yet in both cases it was content to reach a decision with no investigation whatsoever as to the political or economic wisdom of its decision. Though the rule be wise in many situations, ${ }^{2 x}$ to apply it mechanically as the Court did in both cases is to ignore the original reasons for its creation. ${ }^{22}$ The inadequacy of this approach to the defining of state power was soon again made evident. In

2s What is an "ineffective" acceptance?

${ }^{16} 259$ U.S. 209, $2 \mathrm{r}_{4}$ (1922).

$$
\begin{aligned}
& { }^{17} 246 \text { U.S. } 357,368 \text { (19I8). } \\
& { }^{18} 259 \text { U.S. 209, 2I2, 214 (Ig22). }
\end{aligned}
$$

29 See Carnahan, op. cit. supra, note ro, at 554 . While the Dodge case was by a majority of five to four, the Liebing case was unanimous. But in subsequent cases the Dodge case is frequently cited and is not treated as overruled by the Liebing decision.

${ }^{20}$ Although Mr. Justice Holmes was one of the majority in the Dodge case, he wrote the opinion for the unanimous Court in the Liebing case. His concluding sentence was: "In whichever way regarded the facts lead to the same conclusion, and although the circumstances may present some temptation to seek a different one by ingenuity, the Constitution and the first principles of legal thinking allow the law of the place where a contract is made to determine the validity and the consequences of the act." Mutual Life Ins. Co. of New York v. Liebing, 259 U.S. 209, 214 (I922).

${ }^{2 x}$ The problem of fairness is, of course, one of degree. The governing desiderata should be the fulfillment of justified expectations and the avoidance of surprise. Rheinstein, Methods of Legal Thought and the Conflict of Laws: A Book Review, to Univ. Chi. L. Rev. 466, 476-77 (I943).

${ }_{22}$ See the dissent of Mr. Justice Brandeis in the Dodge case, 246 U.S., $357,382-83$ (rgr8). 
Aetna Life Ins. Co. v. Dunken ${ }^{23}$ the Court faced almost the same problem that had been presented by the Dodge and Liebing cases. The insured, while a resident of Tennessee, contracted for insurance in a Connecticut company. Since he applied for the policy, and had it delivered, in Tennessee, on the rule quoted from the Liebing case, the contract could be said to have been made in Tennessee. ${ }^{24}$ The policy provided that at the sole option of the insured it could be converted into a life commercial policy on payment of the difference between the premiums already paid and those required under the converted policy. The insured then moved to Texas, whose statutes imposed a penalty on any insurance company failing to make payment thirty days after demand. While residing in Texas, the insured applied to the Tennessee agent to convert the policy. The home office issued the new policy and forwarded it to the Tennessee agent who, in turn, mailed it to the insured. A Texas jury found that it was the company's intent that the new policy become effective when received by the insured. The insured died; the company failed to pay within thirty days. The Court decided that the courts of Texas could not constitutionally apply the Texas penal statute. Their reason was the familiar one already encountered. The conversion of the original policy was fully in accordance with the original contract. "Nothing was left to future agreement." ${ }^{25}$ Since the original contract was made in Tennessee, it followed by inexorable logic that the "subsidiary" contract was also governed by the law of Tennessee. ${ }^{26}$ The similarity to the Liebing case is obvious, but one difference is important. In the Liebing case the state which was allowed authority over the contract was the state of residence of the insured. In the Aetna case, Tennessee at the time of the conversion had only a casual contact with the parties involved. Presumably, the insured in Texas could have acted directly with the Connecticut home office in effecting the conversion. Again, however, the important observation is the mechanical behavior of the Court.

In Alaska Packers Assn. v. Industrial Accident Commission of California, ${ }^{27}$ the Court clearly abandoned the former rule-of-thumb and there, and in succeeding cases, went on to establish a new doctrine. No longer did the Constitution require that blind deference be paid to the state where the contract had been "made." If a contract was made in state X but

$$
{ }^{23} 266 \text { U.S. } 389 \text { (1924). } \quad 24 \text { The court so held. } \quad 25266 \text { U.S. } 389,399 \text { (I924). }
$$

${ }^{36}$ Note the manner in which the Aetna case is cited in Hartford Accident \& Indemnity Co. v. Delta \& Pine Land Co., 292 U.S. I43, I49 (I934); cf. Home Ins. Co. v. Dick, 28I U.S. 397 (1930).

27294 U.S. 532 (1935). 
arose for adjudication in state $Y$, and if both $X$ and $Y$ had statutes applicable to the controversy, the courts of $Y$ could ignore the laws of $X$ and apply the statute of their own state. If the controversy arose in the courts of $X$, they could also apply their own laws, counter to the commands of $Y$. The only constitutional limitation imposed by the Court under the due process and full faith and credit clauses was that the statute be "reasonable"; that is, that the state applying its own law have substantial governmental interests at stake. The new determinant of cases becomes the public policy of the forum, since the Court has indicated that it will allow considerable discretion to the states in applying their own statutes. Of course, the state of the forum may allow the foreign statute to be applied where the contract was "made" in the other state, but it is not bound to do so. ${ }^{28}$

Hoopeston Canning Co. v. Pink ${ }^{29}$ is the most recent Supreme Court manifestation of this attitude. The plaintiffs were part of a large system of reciprocal insurers doing business in many states but linked together for insurance purposes through contracts "made" in Illinois. In issue was the constitutionality of a New York statute, as applied to the plaintiffs, requiring that insurance companies observe certain financial, bookkeeping, and legal practices-whether within or without the state-in order to secure licenses in New York. The plaintiffs argued that the New York law was inapplicable since the contracts were "made" without the state. But the Court upheld the application to the plaintiffs of the New York statute. It held that New York had a reasonably sufficient governmental interest in its local property to warrant the regulation of insurance affecting it. The argument that the contracts were not "made" in New York was dismissed as technical and unsubstantial.

The significant difference of this decision from preceding ones rests in the difficult problem it raises. It was apparently possible for the reciprocal

${ }^{28}$ In Bradford Electric Light Co. Inc. v. Clapper, 286 U.S. I45 (1932), the deceased resided and made a contract of employment in Vermont, but suffered injury and death while temporarily in New Hampshire in the course of his employment. The Court held that the Vermont Workmen's Compensation Law had to be applied even though the suit was brought in New Hampshire. Mr. Justice Stone concurred even though he thought New Hampshire could not be forced to apply the Vermont statue in preference to its own law because he presumed the New Hampshire court would decide the case as the Supreme Court had done. His concurring opinion is the forerunner of the present position of the Court. See also Osborn v. Ozlin, 3Io U.S. 53 (I940); Griffin v. McCoach, 3 I $_{3}$ U.S. 498 (1941).

The new attitude raises interest as to the future history of the celebrated case of Fauntleroy v. Lum, 2ro U.S. 230 (Ig08), where the Court held that Mississippi had to recognize a Missouri judgment obtained on a gambling transaction in cotton futures in Mississippi even though the laws of Mississippi made such a dealing a misdemeanor. The full faith and credit clause makes no distinction between "public acts" and "judicial proceedings."

2963 S. Ct. 602 (r943). 
insurers in the Hoopeston case to conform their practices to the New York statutes and still operate in other states. Suppose, however, that Illinois, where the attorney-in-fact through whom the contracts were "made" resides, or some other state where the group carries on a considerable insurance business, enacts statutes requiring financial, legal, or book-keeping practices different from those required by New York? Since both statutes would apply to all operations, whether within the state or without, the dilemma raised by the conflict would make continued operation of the business impossible. In such a situation, the Court would be forced to command that one of the two states yield to the other. The Court could no longer say that each state was free to apply its own statutes, based on its own public policy, within its own borders.

But though the mechanical rule-of-thumb is now being disregarded in many situations, it still has vitality. The recent case of United States $v$. Curtiss Aeroplane $C 0 .^{30}$ is an example of how blindly the rule may still be applied. Here the United States, as assignee, was suing the Curtiss Co. for breaches of contracts made between the Curtiss Co. and the Imperial Russian Government. The terms of the contract are incompletely reported, but delivery was to be in New York, "transportation to Russia at the expense and risk of the latter [Russia], and demonstrations in Russia at expense and risk of [Curtiss]." $3 x$ After also noting that "the defendant was a New York corporation" $3^{2}$ - which, of course, has nothing to do with where the contract is "made"-the court summarily concluded: "These facts do not justify any conclusion other than that the New York rule of limitations [that is, New York law] shall govern." ${ }_{33}$

It may be that applying the law of New York was the wisest decision. The point is, however, that no investigation whatsoever was made or even thought necessary as to the wisdom of the choice of law. ${ }^{34}$ Since the place of performance has often been held the place whose law shall govern the contract, ${ }^{35}$ the habit patterns of the court were not disturbed. It could note that New York was the place of delivery, and then it was content that no more was necessary.

The status of the mechanical rule is, therefore, confused. It may or may not be applied, depending probably on the facts, the arguments of counsel,

${ }^{30} 5^{\circ}$ F. Supp. 477 (N.Y. 1943). 32 Tbid.

${ }^{32}$ Ibid., at 487 . 33 Ibid.

34 It should be said in the court's defense that the plaintiff was guilty of poor pleading. While it complained that the plaintiff had failed "to set forth the Russian law applicable to the complex questions," it neglected to allege the Russian law or that the Russian law governed the case.

35 Note 7 , supra. 
and the attitude of the courts. Its demise to the extent noted, however, is to be welcomed. The more recent Supreme Court approach tries to pay attention to underlying conceptions of state policy. ${ }^{36}$ This seems a more reasonable basis for rules of law than what might be called a "jurisprudence of conceptions." Yet, as indicated, this rule raises problems of its own. Conflicts and confusion may result. The increasing power of the states to travel independent paths of social policy may well be undesirable in a nation whose problems are nation-wide in scope and whose aim is interstate harmony.

The Constitution of the United States provides an adequate remedy. Section I of Article 4 declares: "Full Faith and Credit shall be given in each State to the public Acts, Records, and judicial Proceedings of every other State. And the Congress may by general Laws prescribe the Manner in which such Acts, Records and Proceedings shall be proved, and the Effect thereof." "37 Thus far Congress has only slightly used this power; yet it seems broad enough to empower Congress to work out principles sufficient to dispel the present uncertainties. ${ }^{38}$

\section{THE RULE IN SHELLEY'S CASE-AN ARGUMENT FOR ITS ABROGATION}

$T$ devised certain property to A for life with a remainder to A's surviving children. The devise further provided, that if A died leaving no children surviving her, then the "title to the real estate named in this item to vest in fee simple in the brothers \& sisters and their heirs, of her the said [A] who may survive her." A's brothers and three sons of her deceased sister quit-claimed all their interest in the premises to A. Some forty years later, A died leaving no children surviving her. Her three brothers and her sister had predeceased her. A sought to dispose of the property by will. Certain children, the heirs of the brothers and sister, contended that the word "heirs" in the devise over to the "brothers and sisters and their heirs" designated them as a class of purchasers. In answer to this contention, the court held that "the words 'their heirs' are words of limitation and not of purchase and the rule in Shelley's Case

\footnotetext{
${ }^{36}$ Even in the Hoopeston case the Court's analysis was simplified, however. Only the social policy of New York was considered. The problems of Illinois, if any, and their relation to the general problem of regulation were ignored.

${ }^{37}$ Italics added.

${ }^{38} \mathrm{Cook}$, The Powers of Congress under the Full Faith and Credit Clause, 28 Yale L. J. 42I (IgIg), reprinted as chapter 4 in Cook, The Logical and Legal Bases of the Conflict of Laws (I942).
} 